\title{
Kryteria oceny bezpieczeństwa przed skutkami zderzeń dla pojazdów szynowych do transportu osobowego
}

\begin{abstract}
W artykule przedstawiono kryteria bezpieczeństwa przed skutkami zderzeń dla pojazdów szynowych przeznaczonych do transportu osobowego, do których zalicza się: wagony osobowe, zespoły trakcyjne kolei miejskiej (w tym pojazdy metra), do ruchu lokalnego i regionalnego, tramwaje oraz autobusy szynowe. Główny nacisk położono na bezpieczeństwo pasażerów podczas procesów zderzeń pojazdów szynowych i na kryteria jakie powinny być spetnione, aby zapewnić bezpieczeństwo pasażerom podczas ewentualnych zderzeń.

Praca naukowa finansowana ze środków budżetowych na naukę w latach 2005:2007 jako projekt badawczy pt. ,, Teoretyczne i techniczne możliwości ksztaltowania stref zgniotu ustrojów nośnych pojazdów szynowych."
\end{abstract}

\section{Wstęp}

Kryteria oceny zderzeń, przedsięwzięcia konstrukcyjne oraz materiałowe, zabezpieczające strukturę pojazdu szynowego przed skutkami zderzeń dotyczyły w dotychczasowych publikacjach projektu badawczego $[4,5$ i 6] wagonów towarowych. Zwrócono jednak w nich uwagę, że kryteria stawiane pojazdom szynowym przed skutkami zderzeń zależą również od ich przeznaczenia. Zapewnienie bezpieczeństwa $\mathrm{w}$ trakcie „zderzeń nadzwyczajnych” dla pojazdów szynowych przeznaczonych dla przewozów osobowych jest trudniejsze, gdyż ich konstrukcja podczas procesu zderzenia musi zapewnić bezpieczeństwo pasażerów i personelu obsługującego, które sprowadza się do uniknięcia jakichkolwiek obrażeń oraz wypadków śmiertelnych. Zgodnie z dotychczas obowiązującymi przepisami dla wagonów osobowych, przy ich konstruowaniu należy brać pod uwagę jedynie sprężysty zakres odkształceń przy występowaniu obciążeń statycznych. Uwzględniają one również obciążenie, które wynika z sił występujących przy prędkościach nabiegania do $10 \mathrm{~km} / \mathrm{h}(2,77 \mathrm{~m} / \mathrm{s})$ zgodnie z kartą UIC 566 [17]. Jak wynika $\mathrm{z}$ dotychczasowych doświadczeń eksploatacyjnych zachowanie się konstrukcji wagonu osobowego jest zadawalające, jeśli prędkość zderzenia (nabiegania) znajduje się w przedziale 10 do $20 \mathrm{~km} / \mathrm{h}$ (2,77 do $5,55 \mathrm{~m} / \mathrm{s})$ [25]. Powyżej prędkości $20 \mathrm{~km} / \mathrm{h}$ występuja już uszkodzenia $\mathrm{w}$ konstrukcji pojazdu, które mogę wywołać ciężkie obrażenia pasażerów. W związku z tym w ostatnich latach międzynarodowe organizacje kolejowe oraz normalizacyjne jak ERRI, UIC oraz CEN postanowiły podnieść rolę ,pasywnego bezpieczeństwa" pojazdów osobowych do rangi obligatoryjnej oraz sformułowały wytyczne i kryteria dotyczace tej problematyki [17,22,23,24 i 25]. Zgodnie $\mathrm{z}$ raportem ERRI B106/Rp.20 [25] w celu opracowania miarodajnych wytycznych oraz kryteriów oceny ustalono najpierw podstawowe definicje doty- czące zderzeń. Stwierdzono, że zdefiniowanie zderzenia ( wypadku) nie jest możliwe bez podania warunków, podczas których pojazd będzie wykazywał zachowanie zgodne z założeniami. Niebezpieczeństwa kolizji i związane $\mathrm{z}$ tym zagrożenie dla pasażerów można podzielić na dwie kategorie:

$>$ niebezpieczeństwo „, kategorii pierwszej” przy zderzeniu czołowym z ,wspinaniem się" pojazdu lub bez

$>$ niebezpieczeństwo „, kategorii drugiej” przy zderzeniu i w następstwie wykolejeniu się i zdeformowaniu się składu pociągu w kształcie litery ,S”.

\section{Definicje i analiza podstawowych pojęć związanych ze zderzeniami}

\subsection{Kategorie zderzenia}

Zderzenie w kierunku wzdłużnym występuje najczęściej. Jak wynika z praktyki eksploatacyjnej nie można jednak całkowicie wykluczyć zderzenia w kierunku bocznym. Przewrócenia się pojazdu nie uwzględniono w artykule.

Do dalszych rozważań przyjęto następujące kategorie zderzeń:
$>$ zderzenie czołowe
$>$ zderzenie boczne
$>$ zderzenie w kierunku pionowym.

\subsection{Prędkość zderzenia} Analiza parametru w świetle doświadczeń eksploatacyjnych

Z analizy 83 wypadków zgłoszonych przez koleje brytyjskie BR wynika, że:

$>$ w przypadku 36 zderzeń czołowych pociągów osobowych (bez wykolejeń) odnotowano 13 wypadków śmiertelnych 
$>$ w 10 przypadkach pojazdy zderzyły się tak, że wagony składu wjechały między siebie; energia kinetyczna $\mathrm{w}$ dziewięciu przypadkach wynosiła poniżej $25 \mathrm{MJ}$, co dla pociagu o masie równej $400 \mathrm{t}$ odpowiada prędkości mniejszej niż $40 \mathrm{~km} / \mathrm{h}(11 \mathrm{~m} / \mathrm{s})$

$>$ w przypadkach kiedy nie wystapiło zjawisko „wspinania się" pojazdu energia kinetyczna pojazdu wynosiła powyżej $25 \mathrm{MJ}$

$>$ w przypadku zderzenia ze „wspinaniem się” pojazdu energia kinetyczna pojazdu wynosiła $45 \mathrm{MJ}$, co odpowiada prędkości $54 \mathrm{~km} / \mathrm{h}$ ( $15 \mathrm{~m} / \mathrm{s}$ ) dla pociagu o masie $400 \mathrm{t}$

$>32$ zderzenia doprowadziły do wykolejeń, które spowodowały 25 wypadków śmiertelnych

$>$ najwięcej wypadków zderzeń wystąpiło przy prędkości poniżej $40 \mathrm{~km} / \mathrm{h}$ [7].

Formułując definicję prędkości zderzenia, przy której zachowane jest pasywne bezpieczeństwo wagonu osobowego, rozważano inne środki komunikacji jak np. komunikacja lotnicza czy samochodowa.

$\mathrm{Z}$ analizy wypadków przeprowadzonych dla transportu lotniczego, dla którego sporządzono tzw. diagram przeżycia ( niem. „Überlebungsdiagramm”, ang. „,survivale space diagramm") wynika, że pasażerowie nie są chronieni przed skutkami zderzenia czołowego przy prędkości samolotu powyżej $54 \mathrm{~km} / \mathrm{h}(15 \mathrm{~m} / \mathrm{s})$ i maksymalnej prędkości w kierunku pionowym wynoszącej $33 \mathrm{~km} / \mathrm{h}(9,16 \mathrm{~m} / \mathrm{s})$ [8]. W przypadku komunikacji samochodowej maksymalna prędkość, która stwarza zagrożenie dla pasażerów przy zderzeniu czołowym wynosi w zależności od autora 48 do 55 $\mathrm{km} / \mathrm{h}(13,33$ do $15,27 \mathrm{~m} / \mathrm{s})$ [25]. W przypadku bocznego zderzenia zauważono, że niebezpieczeństwo wypadku dla podróżnego zwiększa się wyraźnie od 30 $\mathrm{km} / \mathrm{h}(8,33 \mathrm{~m} / \mathrm{s})$ i przy prędkości $45 \mathrm{~km} / \mathrm{h}(12,5 \mathrm{~m} / \mathrm{s})$ osiaga prawdopodobieństwo równe prawie $100 \%$. Zderzenia $\mathrm{w}$ transporcie lotniczym w kierunku pionowym występują $w$ formie nagłego uderzenia, wywołującego utratę mocy napędowej. W komunikacji samochodowej (samochody osobowe, omnibusy) zderzeniom bocznym towarzyszyły przeważnie przypadki przewrócenia pojazdu. W normie SAE J 374 [19] przedstawiono próby ze zjawiskiem wciśnięcia dachu. Należy jednak zwrócić uwagę na to, że autorzy tej normy $\mathrm{z}$ uwagi na trudności związane $\mathrm{z}$ ustaleniem normatywnej prędkości zderzenia wyszli z założenia, że należy zdefiniować próbę statyczną. $Z$ kolei w normie SAE J 996 [21] ustalono próbę spadania na dach. W przypadku komunikacji kolejowej trzeba się liczyć z tym, że wystąpi wykolejenie z ostatecznym przewróceniem się wagonu osobowego na dach. Wg innych koncepcji pojazdy szynowe w trakcie zderzenia bocznego upadają w większości przypadków na bok ( nie przewracając się na dach) co prowadzi do bardziej prawidłowych rozwiązań. (prawdopodobnie do uprzywilejowania konstrukcji pojazdu z nośnymi elementami rurowymi, powodując zwiększenie wytrzymałości dachu).

W wyniku analizy przypadków referencyjnych ustalenie prędkości zderzenia ma zasadnicze znaczenie $\mathrm{z}$ uwagi na to, że:

$>$ ustalona prędkość zderzenia ma związek z możliwą awarią aktywnych urządzeń sygnalizacyjnych

$>$ ustalona prędkość prowadzi do technicznych rozwiązań, których efektywność przy tej prędkości wprawdzie byłaby optymalna, jednakże nie da się rozszerzyć na inny zakres tzn. pojazd posiadający optymalną konstrukcję dla prędkości $50 \mathrm{~km} / \mathrm{h}(13,88 \mathrm{~m} / \mathrm{s})$ nie musi sprawdzać się dla prędkości zderzenia $100 \mathrm{~km} / \mathrm{h}(27,77 \mathrm{~m} / \mathrm{s})$

$>$ ustalona prędkość zderzenia powoduje zmianę przepisów dotyczących wymiarowania pojazdów, co może prowadzić do zwiększenia masy a zatem wzrostu kosztów wykonania i eksploatacyjnych; taki przypadek może wystąpić, jeśli prędkość zderzenia zostanie ustalona na zbyt wysokim poziomie.

W tabeli 1 przedstawiono kilka wyników obliczeń energii przejętej podczas zderzenia czołowego dwóch niehamowanych pociagów o masie 400 t.

Zestawienie przejętej energii podczas zderzenia dwóch pociągów osobowych o masie 400 t każdy

Tabela 1

\begin{tabular}{|c|c|c|c|c|}
\hline L.p. & $\begin{array}{c}\text { Prędkość } \\
\text { podczas } \\
\text { zderzenia } \\
{[\mathrm{m} / \mathrm{s}]}\end{array}$ & $\begin{array}{c}\text { Energia } \\
\text { kinetyczna } \\
{[\mathrm{kJ}]}\end{array}$ & $\begin{array}{c}\text { Energia } \\
\text { przejęta } \\
\text { przez } \\
\text { konstrukcję } \\
{[\mathrm{kJ}]}\end{array}$ & $\begin{array}{c}\text { Długość } \\
\text { strefy } \\
\text { zniszczenia } \\
\text { dla jednego } \\
\text { pociągu }[\mathrm{m}]\end{array}$ \\
\hline 1. & 10 & 10000 & 10000 & 2,5 \\
\hline 2. & 45 & 45000 & 22500 & 5,6 \\
\hline 3. & 80 & 80000 & 40000 & 10 \\
\hline
\end{tabular}

Energia przejęta $\mathrm{w}$ zakresie całkowicie plastycznym (w odróżnieniu od energii kinetycznej najeżdżającego pociagu i resztkowej energii obydwu pociagów po zderzeniu) prowadzi do projektowania konstrukcji ze strefami przejmowania energii, które odpowiadaja zderzeniu z prędkością $34 \mathrm{~km} / \mathrm{h}(9,44 \mathrm{~m} / \mathrm{s})$ i odkształceniu stref kontrolowanego zniszczenia w zakresie 2,5 m. Jak wynika z tabeli 1 im większa prędkość zderzenia, tym większy zakres odkształcenia plastycznego, ale również zwiększa się ryzyko „unoszenia" się pojazdu. Przy większych prędkościach nie można ograniczyć ryzyka zwiększenia deformacji przedziałów dla podróżnych ze względu na poważne rozmiary odkształcenia stref kontrolowanego zgniotu. Przy rozważaniach dopuszczalnej prędkości zderzeń czołowych jako pierwszą wartość zaproponowano 54 $\mathrm{km} / \mathrm{h}(15 \mathrm{~m} / \mathrm{s})$, w celu zrównania kryteriów przyjętych 
w komunikacji samochodowej. Ostatecznie zgodnie z pr EN 15227 [22] dla pojazdów szynowych kategorii I do IV jako miarodajną prędkość zderzenia przyjęto 36 $\mathrm{km} / \mathrm{h}(10 \mathrm{~m} / \mathrm{s})$, natomiast dla pojazdów kategorii $\mathrm{V}$ (tramwaje) $15 \mathrm{~km} / \mathrm{h}(4,16 \mathrm{~m} / \mathrm{s})$.

\section{Analiza zderzenia bocznego pojazdu szynowego z masztem trakcyjnym sieci jezdnej}

W wyniku przeprowadzonych analiz, za prędkość zderzenia bocznego z masztem trakcyjnym sieci jezdnej uznano prędkość $9,4 \mathrm{~km} / \mathrm{h}(2,6 \mathrm{~m} / \mathrm{s})$, przy której przeważa quasistatyczny efekt zderzenia. Rozpatrując uproszczony model zderzenia bocznego wagonu osobowego $\mathrm{z}$ masztem bilans energetyczny zderzenia można opisać za pomocą równania:

$$
W_{C V}=W_{C P}+W_{D P}+W_{D V}
$$

gdzie:

$W_{C r}$ energia kinetyczna wagonu osobowego

$W_{C P}$-energia kinetyczna masztu trakcyjnej sieci jezdnej

$W_{D P^{-}}$energia plastycznej deformacji masztu trakcyjnego sieci jezdnej

$W_{D V^{-}}$energia plastycznej deformacji wagonu osobowego.

Przy prędkości zderzenia wynoszącej 9,4 km/h ( 2,6 $\mathrm{m} / \mathrm{s}$ ) i masie wagonu osobowego w stanie próżnym 44 $\mathrm{t}$, jego energia kinetyczna wynosi $W_{C V}=150 \mathrm{~kJ}$. Wychodząc z założenia, że wytrzymałość masztu trakcyjnego sieci jezdnej jest stała, to energię plastycznej deformacji obliczonej za pomocą oprogramowania ANSYS w zależności od jego odkształcenia $\mathrm{d}_{\mathrm{P}}$ wyraża się wzorem:

$$
W_{D P}=1,5 \cdot 10^{5} d_{P^{-}} 750 \text { dla } d_{P}>0,01 \mathrm{~m}
$$

W analogiczny sposób ustalono plastyczną energię deformacji wagonu wychodząc z założenia, że wielkość deformacji wagonu wynosi $d_{V}$ oraz wielkości odkształceń plastycznych $d_{V}$ oraz $d_{P}$ są w zależności proporcjonalnej wg wzoru:

$$
W_{D V}=W_{D P} \cdot \frac{d_{V}}{d_{P}}
$$

Energię kinetyczną zgromadzoną w maszcie trakcyjnym sieci jezdnej można ustalić pod warunkiem, że:

$>$ wahania prędkości pojazdu mają liniowy przebieg

$>$ prędkość zderzenia zostaje przeniesiona $\mathrm{z}$ wysokości ostoi ( podwozia) wagonu na maszt sieci trakcyjnej

$>$ rodzaj zniszczenia masztu trakcyjnej sieci jezdnej zależy od wystapienia plastycznego przegubu na zakotwiczeniu, ponieważ maszt poza tym przegubem jest sztywny.
Ostatecznie można przyjąć, że przy $d_{P}>0,01 \mathrm{~m}$ obowiązuje zależność:

$$
1,5 \cdot 10^{5}=0,1 \cdot 10^{5}+1,5 \cdot 10^{5} \cdot\left(d_{P}+d_{V}\right)-750 \cdot\left(1+\frac{d_{V}}{d_{P}}\right)
$$

Jeśli przyjać ze względów bezpieczeństwa dla podróżnych $d_{V}=0,3 m$ wówczas równanie (4) przyjmuje postać:

$$
1,5 \cdot 10^{5} \cdot d_{P}^{2}-94250 \cdot d_{P}-225=0
$$

Równanie (5) posiada jedno rozwiązanie mające sens techniczny tzn. $d_{P}=0,631 \mathrm{~m}$, co odpowiada kątowi pochylenia masztu sieci trakcyjnej wynoszącemu $\alpha=22^{\circ}$ (rys.1). Model obliczeniowy ogranicza przesunięcie punktu styku masztu sieci jezdnej i podwozia wagonu do $\mathrm{d}=0,7 \mathrm{~m}$ oraz wielkość deformacji bocznej nadwozia do max. 0,3 m ( rys.1).

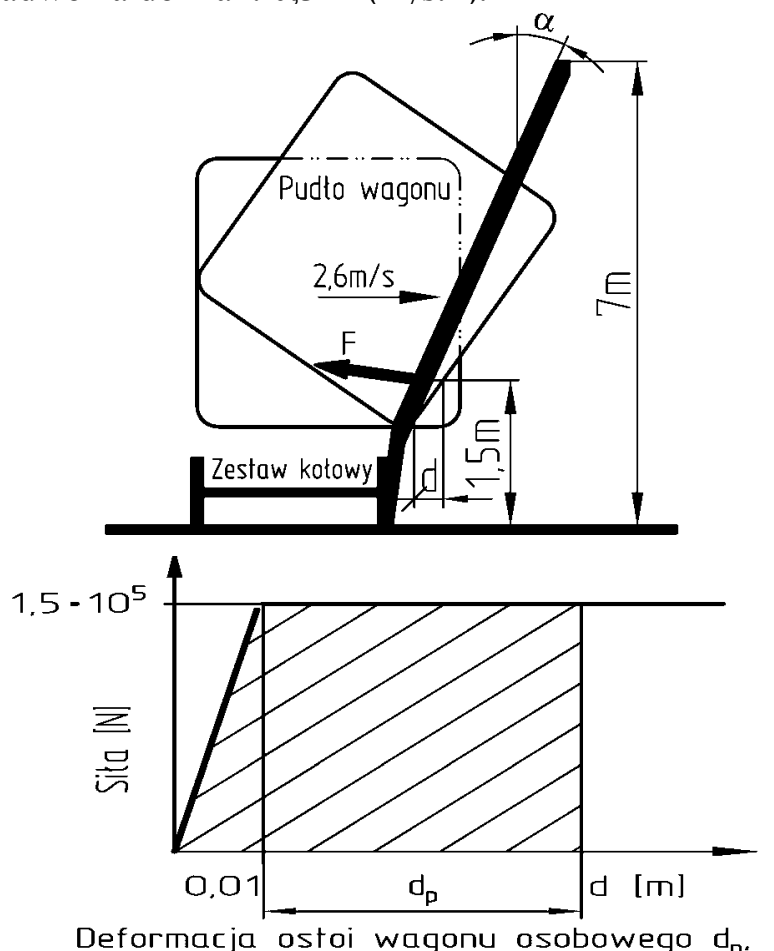

Deformacja ostoi wagonu osobowego $d_{p}$. spowadowana masztem sieci trakcyjnej

Rys.1. Zderzenie wagonu osobowego z masztem sieci trakcyjnej

Kolejnym przypadkiem, który należy rozważyć, jest uderzenie boczne z przeszkodą w postaci wahadła (rys.2).

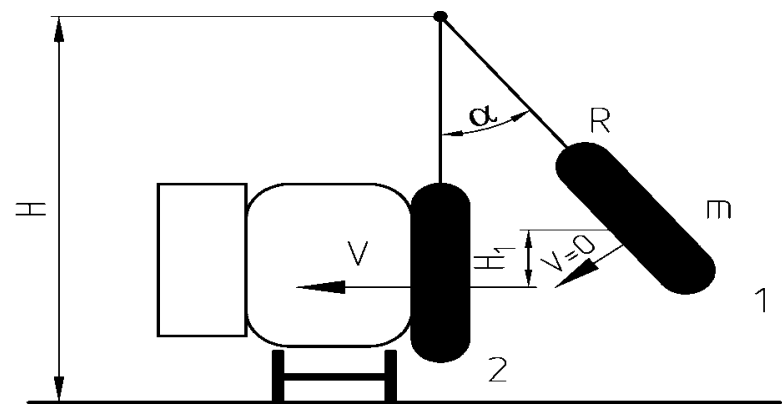

Rys.2. Zderzenie wagonu osobowego $\mathrm{z}$ elementem o masie $\mathrm{m}$ w postaci wahadła 
Zderzenie $\mathrm{z}$ wagonem osobowym wywołuje masa $\mathrm{w}$ postaci wahadła odchylnego od pionu pod kątem $\alpha$ i przemieszczająca się z pozycji 1 do położenia 2 . Boczna prędkość zderzenia $\mathrm{z}$ wagonem osobowym w pozycji 2 wynosi:

$$
v=\sqrt{2 g R \cdot(1-\cos \alpha)}
$$

gdzie:

$$
\text { g- przyspieszenie ziemskie }\left[9,81 \mathrm{~m} / \mathrm{s}^{2}\right]
$$

$\mathrm{R}$-promień wahadła [m].

Jeśli podstawi się prędkość zderzenia wynosząca $\mathrm{v}=2,6 \mathrm{~m} / \mathrm{s}(9,4 \mathrm{~km} / \mathrm{h})$, to wówczas otrzymuje się wysokość $\mathrm{H}_{1}$ po zderzeniu wynoszącą:

$$
H_{1}=R \cdot(1-\cos \alpha)=0,345 m
$$

Jeśli przyjmie się, że wysokość $\mathrm{H}$ nie wynosi więcej niż $10 \mathrm{~m}$, wówczas można wyjść z założenia, że $\mathrm{R}=7$ $\mathrm{m}$, co w tym przypadku daje $\alpha=18,2^{\circ}$. Ponieważ energia kinetyczna wagonu osobowego w stanie próżnym o masie $44 \mathrm{t}$ przy prędkości $\mathrm{v}=2,6 \mathrm{~m} / \mathrm{s}$ jest równa 0,15 MJ, aby wywołać taki sam efekt zderzenia jak w przypadku poprzednim, musiałaby masa uderzającego wahadła m odpowiadać masie wagonu osobowego, co należy zaliczyć do przypadków hipotetycznych i rzadko spotykanych w rzeczywistości .Taka próba byłaby interesująca, gdyby chciało się zbadać dynamikę uderzenia skierowanego $\mathrm{w}$ stronę manekinów, znajdujących się po przeciwnej stronie względem strony bocznej na wysokości zderzenia. Jak wynika z praktyki, zrealizowanie takiej próby mogłoby się okazać trudne, aby dokonać symulacji zderzenia odpowiadającemu w rzeczywistości deformacji plastycznej, pochłaniającej trzecią część energii tzn. taka próba nie posiada miarodajnej, wystarczającej siły.

Kolejnym zagadnieniem, które należy przeanalizować, jest sformułowanie kryteriów dla bocznego zderzenia nie wywołującego większej deformacji niż 0,3 $\mathrm{m}$, skierowanej do wnętrza pudła wagonu. Jak wynika $\mathrm{z}$ dotychczasowego stanu wiedzy przypadek ten wymaga badań doświadczalnych, aby można było opracować odpowiednie normy w tym zakresie [25].

Jako próby kwalifikacyjne dla pojazdów gwarantujących „pasywne bezpieczeństwo” przed skutkami zderzeń zaproponowano, aby próby zderzenia realizować jako próby zderzenia czołowego, $\mathrm{w}$ formie zderzenia pociagu jadącego z prędkością $54 \mathrm{~km} / \mathrm{h}(15 \mathrm{~m} / \mathrm{s})$ na stojący pociagg w stanie niezahamowanym. Kryteria odbiorcze odpowiedniego pojazdu zależą od kryteriów biomechanicznych i od kryteriów zachowania konstrukcji. Kryteria biomechaniczne zostały sformułowane w zależności od wyników pomiarów wykonanych na manekinach, symulujących pasażerów. W tym przypadku należy zwrócić uwagę na paradoksalną sytuację bezpieczeństwa w komunikacji samochodowej w stosunku do bezpieczeństwa $\mathrm{w}$ pojazdach szynowych. Dzięki rozległym staraniom, dotyczącym bezpieczeństwa pasażerów przy zderzeniu czołowym i bocznym, udało się w przemyśle samochodowym wyprodukowanie bezpiecznych samochodów, pomimo że pomiary dokonane na manekinach wykazały, iż przyspieszenia przekraczają wartości $100 \mathrm{~g}\left(981 \mathrm{~m} / \mathrm{s}^{2}\right)$. Jednocześnie w wypadkach kolejowych zdarzały się ciężkie obrażenia pasażerów, pomimo że obliczone opóźnienia wykazywały wartości mniejsze niż $10 \mathrm{~g}$ $\left(98,1 \mathrm{~m} / \mathrm{s}^{2}\right)$. Stąd też wynikła potrzeba opracowania takich metod obliczeń, które gwarantują brak obrażeń pasażerów znajdujących się $\mathrm{w}$ przedziałach dla podróżnych w przypadku ewentualnego zderzenia pojazdu. Urządzenia wyposażenia wewnętrznego pojazdu muszą być tak ukształtowane, aby obrażenia pasażera przy powtórnym uderzeniu o urządzenie $\mathrm{z}$ jego przedziału były w dopuszczalnych granicach.

\subsection{Biomechanika i jej podstawowe pojęcia}

Biomechanika jest nauką zachowania się ciała ludzkiego w przypadku działania na niego różnych obciążeń. Biomechanika zderzenia jest częścią składową biomechaniki, która zajmuje się reakcją ciała ludzkiego na siły i przyspieszenia, wynikające ze zderzenia. Ten zakres w ogólnym przypadku można podzielić na trzy dziedziny:

-reakcje mechaniczne

-mechanizm obrażeń

-poziom tolerancji.

W związku z tym zwrócono uwage $\mathrm{w}$ amerykańskich przepisach na to, że poziom tolerancji amplitudy sygnału przedstawia określony stopień obrażeń, podczas gdy przy specyfikacji dotyczącej tolerancji chodzi o ustaloną dowolną odporność na zderzenia. Koncepcja bezpiecznego wyposażenia odpowiada stopniowi umiarkowanego lub małego zranienia. Mechaniczne zachowanie ciała ludzkiego i innych żywych istot można tak dokładnie uzasadnić, jak innych konstrukcji, jeśli zastosuje się pomiary przyspieszenia, prędkości, przemieszczeń oraz deformacji , a wyniki pomiarów powiąże się z siłami powodującymi te procesy. Za pomocą jednej ze zmiennych wielkości, które charakteryzują mechaniczną reakcję, można dokonać próby oszacowania prawdopodobnej wielkości ewentualnych obrażeń, wskutek czego można ustalić związek pomiędzy występującymi zmiennymi wielkościami fizycznymi oraz stopniem obrażeń pasażerów. Ze względu na wiele organów, z których składa się ciało człowieka i możliwych rodzajów obciążeń, nie można ustalić żadnego ogólnego kryterium dla stanu pasażera po zderzeniu. Przy wielu obrażeniach każde $\mathrm{z}$ nich posiada swoją własną ważkość i stosowanie metody superpozycji przez dodawanie stopni ciężkości nie stwarza żadnego obrazu ogólnego stanu poszkodowanych. W przypadku wielu obrażeń każde z nich posiada swój własny stopień ciężkości.

W celu oceny obrażeń z wypadków ulicznych wykorzystuje się tabelę obrażeń, wyrażonych w stopniach AIS (ang. „Abbreviate Injury Scale”). Odpowiednie stopnie ( kategorie) AIS sa przedstawione w tabeli 2. 
Zestawienie stopni ( kategorii) obrażeń AIS [25]

Tabela 2

\begin{tabular}{|c|c|c|}
\hline L.p. & $\begin{array}{c}\text { Nr kodu } \\
\text { AIS }\end{array}$ & Opis kategorii obrażenia \\
\hline 1 & 1 & małe \\
\hline 2 & 2 & przeciętne \\
\hline 3 & 3 & poważne \\
\hline 4 & 4 & ciężkie \\
\hline 5 & 5 & $\begin{array}{c}\text { krytyczne ( szanse przeżycia } \\
\text { niepewne) }\end{array}$ \\
\hline 6 & 6 & $\begin{array}{c}\text { maksymalne (praktycznie } \\
\text { przypadek śmiertelny) }\end{array}$ \\
\hline 7 & 9 & nieznane \\
\hline
\end{tabular}

Porównując obrażenia przy wypadkach ulicznych w skali AIS należy pamiętać, że np. obrażenie wg kodu 4 nie ma takiego samego znaczenia jak dwa obrażenia wg kodu 2.

W komunikacji samochodowej, gdzie wypadki występują znacznie częściej, można sporządzić odpowiednie statystyki, aby określić najgroźniejsze części pojazdu dla pasażera, jednak ich wyników nie można porównać $\mathrm{z}$ wypadkami w pojazdach szynowych ani ekstrapolować ze względu na różne wyposażenie samochodów ciężarowych i pociagów.

\section{Klasyfikacja sił powodujących urazy glowy i szyi pasażera}

W wyniku przeprowadzonych prac studialnych, dotyczących mechanizmów powodujących obrażenia głowy oraz szyi pasażerów pojazdów szynowych, przyjęto jako zasadnicze dwa rodzaje sił występujących podczas zderzenia pojazdów szynowych:

- sily przylegania (niem. Berührungskräfte): siły podczas zderzeń pojazdów szynowych zależne od przyspieszenia; pojawiają się wtedy, gdy oparta głowa podczas zderzenia pasażera uderza o przedmiot i wskutek tego podnosi się lub jest wprawiona $\mathrm{w}$ ruch; wskutek działania tych sił powstają np. pęknięcia czaszki, stłuczenia i najczęściej krwiaki, ale nie ma żadnych rozległych i rozproszonych uszkodzeń mózgu

- sily bezwladności (niem. Beharrungskräfte): siły występują w przypadku gwałtownego przyspieszenia lub opóźnienia głowy, wskutek czego niekonieczny jest styk z przedmiotem, aby wywołać obrażenia; ważna jest identyfikacja rodzaju przyspieszenia, ponieważ wstrząsy mózgu moga powstać tylko podczas przyspieszenia działającego na głowę i skierowanego pod kątem, natomiast liniowe przyspieszenia mogą spowodować lokalne urazy jak np. stłuczenia karku oraz krwiaki na głowie i otaczającej go skórze.

Siły powodujące urazy czaszki pasażera przy uderzeniach sztywnych ( nietłumionych) oraz thumionych sa przedstawione $\mathrm{w}$ tabeli 3. Są to wyniki badań laboratoryjnych na małej liczbie próbek, przeprowadzone dla celów informacyjnych.

Jak wynika z tabeli 3 przy sztywnym, nietłumionym uderzeniu na kość czołową średnia siła wywołująca uraz znajduje się na poziomie $6 \mathrm{kN}$, przy czym powierzchnie uderzenia poniżej $5 \mathrm{~cm}^{2}$ moga $w$ tym przypadku wywołać uszkodzenie czaszki już poniżej tej wartości. Znaczną rolę w tym przypadku pełni wykładzina tłumiąca, która znacznie podnosi średnią wartość powodująca uraz tej części głowy ( o przynajmniej 22\%). Uderzenia skierowane $\mathrm{w}$ bok głowy pasażera (kość ciemieniowa/ kość skroniowa) są bardziej dotkliwe w skutkach, zwłaszcza z przedmiotami o małej średnicy, gdzie średnia siła wynosi najwyżej $4 \mathrm{kN}$.

W przypadku płaskich powierzchni boczna strona głowy ( kość skroniowa) wykazuje się podobną odpornością na uderzenia jak kość czołowa. Wyniki badań przedstawione $\mathrm{w}$ tabeli 3 stanowią wytyczne do projektowania urządzeń wewnętrznych w pojeździe samochodowym oraz $\mathrm{w}$ pojeździe szynowym, biorąc pod uwagę kryterium „bezpieczeństwa pasywnego” pasażera przed skutkami zderzeń.

Sily przylegania powodujące urazy czaszki pasażera podczas zderzenia pojazdów [25]

Tabela 3

\begin{tabular}{|c|c|c|c|c|}
\hline \multirow[t]{2}{*}{ L.p. } & \multirow{2}{*}{$\begin{array}{l}\text { Rodzaj uderzanej po- } \\
\text { wierzchni/ uderzenia }\end{array}$} & \multicolumn{2}{|c|}{ Siła przylegania wywołująca złamanie $[\mathrm{N}]$} & \multirow{2}{*}{ Liczba próbek } \\
\hline & & Wartość średnia & Przedział wartości & \\
\hline \multicolumn{5}{|c|}{ Sztywne ( nietłumione) uderzenia } \\
\hline \multicolumn{5}{|c|}{ Kość czołowa } \\
\hline 1. & Powierzchnia płaska & 6360 & $3910 \div 11790$ & 12 \\
\hline 2. & Powierzchnia płaska & 6400 & $5420 \div 7870$ & 6 \\
\hline 3. & $\begin{array}{l}\text { Powierzchnia wzdłużna } \\
\text { cylindryczna: }\end{array}$ & & & \\
\hline a & $\begin{array}{l}\varnothing 50 \mathrm{~mm} \text { w kierunku } \\
\text { poprzecznym }\end{array}$ & 5600 & $4220 \div 7340$ & 7 \\
\hline $\mathrm{b}$ & $\varnothing 50 \mathrm{~mm}$ sagitalna & 7120 & $4180 \div 8900$ & 5 \\
\hline $\mathrm{c}$ & $\begin{array}{l}\varnothing 15,8 \mathrm{~mm} \text { w kierunku } \\
\text { poprzecznym }\end{array}$ & 5470 & $3110 \div 7700$ & 5 \\
\hline $\mathrm{d}$ & $\begin{array}{l}\text { Kula o średnicy } \varnothing 406 \\
\text { mm }\end{array}$ & 5250 & $3690 \div 6810$ & 5 \\
\hline
\end{tabular}




\begin{tabular}{|c|c|c|c|c|}
\hline 4. & $\begin{array}{l}\text { Płaska powierzchnia o } \\
\text { małym polu: }\end{array}$ & & & \\
\hline $\mathrm{a}$ & Średnica $\varnothing 29 \mathrm{~mm}$ & 5030 & $3770 \div 7120$ & 5 \\
\hline $\mathrm{b}$ & Średnica $\varnothing 29 \mathrm{~mm}$ & 6180 & $4360 \div 8850$ & 5 \\
\hline $\mathrm{c}$ & Średnica $\varnothing 29 \mathrm{~mm}$ & 5830 & $4140 \div 9880$ & 7 \\
\hline $\mathrm{d}$ & Średnica $\varnothing 15,5 \mathrm{~mm}$ & 7610 & $4090 \div 9790$ & 5 \\
\hline $\mathrm{e}$ & Średnica $\varnothing 10,9 \mathrm{~mm}$ & 4580 & $2090 \div 8900$ & 5 \\
\hline 5. & $\begin{array}{l}\text { Wypukła powierzchnia } \\
\text { o małym polu wynika- } \\
\text { jącym ze średnicy } \varnothing 17 \\
\text { mm }\end{array}$ & 4450 & $2760 \div 8100$ & 6 \\
\hline \multicolumn{5}{|c|}{ Kość ciemieniowa/ kość skroniowa } \\
\hline 6. & Płaska powierzchnia & 5070 & $3430 \div 7830$ & 13 \\
\hline 7. & Płaska powierzchnia & 8500 & $4670 \div 14590$ & 7 \\
\hline 8. & $\begin{array}{l}\text { Płaska powierzchnia o } \\
\text { małym polu: }\end{array}$ & & & \\
\hline a & Średnica $\varnothing 29 \mathrm{~mm}$ & 3760 & $2450 \div 5920$ & 7 \\
\hline $\mathrm{b}$ & Średnica $\varnothing 29 \mathrm{~mm}$ & 3120 & $1340 \div 5920$ & 8 \\
\hline $\mathrm{c}$ & Średnica $\varnothing 15,5 \mathrm{~mm}$ & 5740 & $2220 \div 9790$ & 10 \\
\hline $\mathrm{d}$ & Średnica $\varnothing \quad 10,9 \mathrm{~mm}$ & 3470 & $620 \div 6670$ & 10 \\
\hline 9. & $\begin{array}{l}\text { Wypukła powierzchnia } \\
\text { o małym polu wynika- } \\
\text { jącym ze średnicy } \varnothing 17 \\
\text { mm }\end{array}$ & 3410 & $1780 \div 4890$ & 7 \\
\hline \multicolumn{5}{|c|}{ Kość potyliczna } \\
\hline 10. & $\begin{array}{l}\text { Wypukła powierzchnia } \\
\text { o małym polu wynika- } \\
\text { jącym ze średnicy } \varnothing 17 \\
\text { mm }\end{array}$ & 6410 & $5120 \div 9560$ & 5 \\
\hline \multicolumn{5}{|c|}{ Uderzenia thumione } \\
\hline \multicolumn{5}{|c|}{ Kość czołowa } \\
\hline 11. & $\begin{array}{l}\text { Powierzchnia pokryta } \\
\text { wykładziną o własno- } \\
\text { ściach tłumiących: }\end{array}$ & & & \\
\hline $\mathrm{a}$ & Powierzchnia płaska & 11260 & $5340 \div 15100$ & 7 \\
\hline $\mathrm{b}$ & $\begin{array}{l}\text { Powierzchnia płaska o } \\
\text { małym polu odp. } \\
\text { średnicy Ø } 25 \mathrm{~mm}\end{array}$ & 7340 & $4890 \div 8720$ & 6 \\
\hline
\end{tabular}

\section{Kryteria biomecha- niczne przed skut- kami zderzeń}

\subsection{Kryteria dotyczące} uszkodzenia mózgu i obrażeń

Do oceny stłuczeń gło-wy, jako skutku działań czysto liniowych przyspieszeń, zaproponowano najpierw krzywą tolerancji, przedstawioną na rys.3 [20].

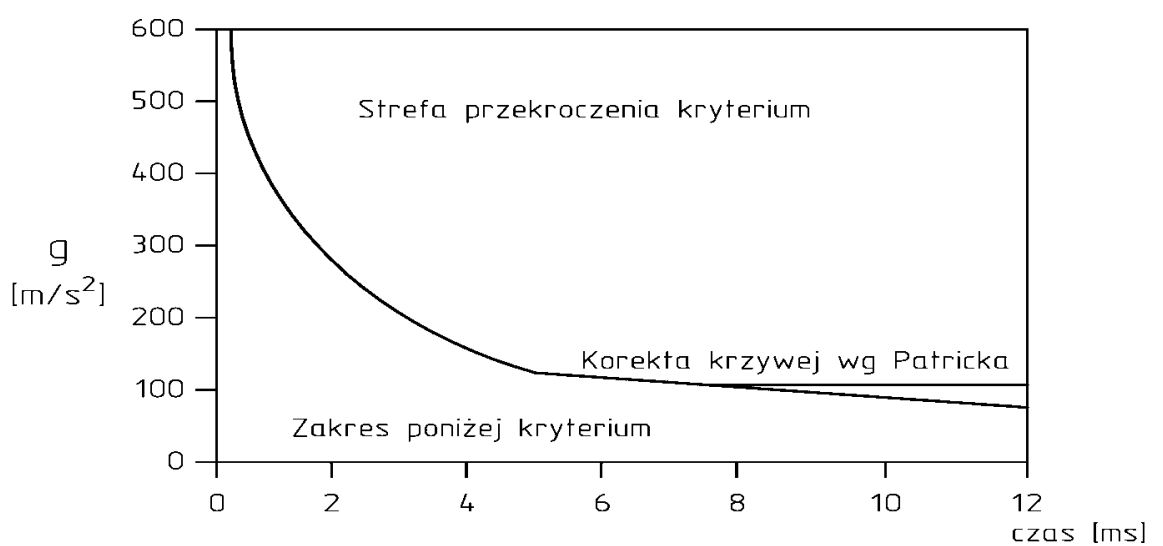

Rys.3. Krzywa przyspieszeń liniowych działających na głowę pasażera 
Analizując krzywą przedstawioną na rys.3 można stwierdzić, że uraz glowy jest zależny od wielkości przyspieszenia działającego w kierunku przód-tył, wywołanego uderzeniem w kość czołową i mierzonego w rejonie kości potylicznej (sięgającego nawet wielkości $\left.600 \mathrm{~g}\left(5886 \mathrm{~m} / \mathrm{s}^{2}\right)\right)$ oraz czasu jego działania wyrażonego w milisekundach ( $\max .12 \mathrm{~ms}$ ). Krzywa ta jest znana jako Wayne State University Tolerance Curve ( w skrócie WSTC) [20] i była przez długi czas stosowana do oceny niebezpieczeństwa powstania urazów głowy, pomimo rozlicznych braków, do których zalicza się:

$>$ stosowanie różnych metod empirycznych podczas badań, służących do ustalenia danych tzn. przy dużych przyspieszeniach badań dokonywano na zwierzętach, natomiast przy małych przyspieszeniach krzywa powstała w wyniku badań na ochotnikach, przy czym ich głowa była unieruchomiona.

$>$ powstały wątpliwości, jak wielkie przyspieszenie może działać na głowę pasażera w przeciagu dłuższego czasu; w wyni$\mathrm{ku}$ przeprowadzonej korekty asymptota krzywej WSTC została zwiększona z 42g $\left(412 \mathrm{~m} / \mathrm{s}^{2}\right)$ na $80 \mathrm{~g}\left(784.8 \mathrm{~m} / \mathrm{s}^{2}\right)$.

Kolejnym kryterium, które zostało wprowadzone w amerykańskiej normie jest tzw. Head Injury Criterion ( HIC), które wyraża zależność wg [1]:

$$
H I C=\left[\left(t_{2}-t_{1}\right)\left\{\frac{1}{\left(t_{2}-t_{1}\right)} \int_{t_{1}}^{t_{2}} a(t) d t\right\}^{2.5}\right]<1000
$$

gdzie:

$t_{1}$ i $t_{2}$ - odpowiednio czas rozpoczęcia $\mathrm{i}$ końca przedziału czasowego wyrażony w sekundach, w stosunku do którego odnosi się wskaźnik HIC

a- przyspieszenie, wyrażone jako krotność przyspieszenia ziemskiego g, działające na punkt ciężkości głowy pasażera ( $\mathrm{wg}$ rys.3).

Wskaźnik HIC jest stosowany do wszystkich biomechanicznych kryteriów oceny a mianowicie:

$>$ określenia tolerancji dla ludzkiego ciała lub przeprowadzenia badań wypadków ze zwłokami ludzkimi

$>$ zastosowania manekinów do symulacji wypadków na poślizg z dużym opóźnieniem hamowania, przeprowadzenia badań z obiektami materialnymi wyposażonymi $\mathrm{w}$ materiały $\mathrm{o}$ własnościach thumiących względnie sprawdzenie wszystkich systemów, które zwiększają pasywne bezpieczeństwo pojazdu szynowego
$>$ numerycznego określenia biomechanicznego kryterium na podstawie liniowego przyspieszenia, działającego na środek ciężkości głowy.

Ponieważ wskaźnik HIC wywodzi się z kontrowersyjnej krzywej WSTC, nie można było udzielić mu powszechnej akceptacji do uniwersalnego zastosowania. Jednym z powodów było nieuwzględnienie przyspieszenia obrotowego, którego występowanie obowiązuje dla większości kryteriów. Pomimo, że obydwa rodzaje przyspieszeń nie powodują tych samych rodzajów obrażeń, wszystkie ich mechanizmy można było sprowadzić do wartości liniowego przyspieszenia. Wahania wartości wskaźnika HIC sprowadzają się nie tylko do różnic pomiędzy przypadkami indywidualnymi, ale również do rodzaju i sposobu, w których odbywają się wypadki, co obowiązuje zwłaszcza przy doświadczeniach z manekinami. Oprócz tego zwrócono uwagę na to, że pomiędzy wartościami wskaźnika HIC i skali AIS nie występuje zamienność, co było kolejnym argumentem przeciwko jego zastosowaniu. Kontrowersje wzbudziło zastosowanie kryterium (progu) bezpieczeństwa na poziomie $\mathrm{HIC}=1000$ lub HIC $=1500$. Zwrócono uwagę na to, że przy zastosowaniu $\mathrm{HIC}=1000$ jest zagwarantowana ochrona głowy pasażera przy sztywnych uderzeniach o krótkotrwałym działaniu, podczas gdy próg o wartości 1500 stanowi dobrą ochronę głowy przy bezpośrednim czołowym lub bocznym kontakcie jak również przy rekonstrukcjach wypadków pasażerów z zapiętymi pasami. Amerykańska norma SAE J885 [20] zaleca próg o wartości 1000, który wykorzystuje wielu badaczy. Trudno nie zgodzić się ze stwierdzeniem, że o ile nie ma bardziej zadawalającego kryterium o uniwersalnym znaczeniu, wskaźnik HIC może być zastosowany jako podstawa do wzajemnych porównań rozwiązań. Reasumując, za pomocą wskaźnika HIC można ocenić, czy występuje niebezpieczeństwo powstania obrażeń czy nie, ale nie dostarcza on stopniowanego oszacowania tego niebezpieczeństwa, co było powodem poszukiwania następnych, doskonalszych kryteriów.

Inne kryteria wynikały z przyjęcia modelu w kształcie masy jako bryły sztywnej, elementów sprężystych oraz thumiących.

Do innych kryteriów zalicza się:

$>$ Wskaźnik Tolerancji JTI ( ang. , J- Tolerances Index")

$>$ Przerobiony Model Mózgu RBM ( ang. „Revised Brain Model")

$>$ Wskaźnik Rzeczywistego Odkształcenia EDI ( ang. ,Effective Displacement Index”)

> Wskaźnik Przeciętnego Odkształcenia MSC (ang. „Mean Strain Criterion”). 
Ostatnie kryterium jest jedynym, które nie ma żadnego powiązania z krzywą WSTC. Kryterium przeciętnego odkształcenia MSC jest jedynym liniowym kryterium, które powinno być brane pod uwage przy analizach wypadków, ponieważ powstało jako wynik rozlicznych badań przeprowadzonych na głowach pasażerów.

Rozwój kryteriów nie został zahamowany wskutek postępu dalszych badań w tym zakresie. Przykładem tego jest opracowanie przez zespół badawczy R.L. Stalnakera kryterium dla powstania urazów głowy, które polega na przepływie energii (ang. „Translational Energy Criterion”-TEC) [10].Za pomoca ,metody energetycznej" można przewidzieć powstanie zarówno stłuczeń jak również pęknięć czaszki. Jak wynika z [25], obecny stan wiedzy w tym zakresie nie pozwala na jednoznaczne stwierdzenie, które kryterium należy stosować oraz które ma charakter uniwersalny.

Porównując wszystkie kryteria nasuwają się następujące spostrzeżenia:

$>$ kryterium wg wskaźnika HIC jest jedynym, które jest wynikiem rozlicznych badań i za pomocą którego można ustalić granice jego zastosowania

w celu ustalenia wymagań dla głowy przy bocznym uderzeniu można zastosować kryteria HIC, MSC i TEC przy czołowym uderzeniu.

Zespół badawczy Stalnakera zaproponował próg dla przyspieszenia wynoszącego $20 \mathrm{~g}\left(196.2 \mathrm{~m} / \mathrm{s}^{2}\right)$ w czasie działania wynoszacym 20 milisekund [10]. Po szeregu badaniach eksperymentalnych Huelke i Melwin doszli do wniosku, że ciężkie obrażenia występują przy prędkości zderzenia wynoszącej $33 \mathrm{~km} / \mathrm{h}(9,2$ $\mathrm{m} / \mathrm{s}$ ) [2]. W wyniku badań za pomocą miękkiego uderzenia i występujących przy tym krwotoków na bocznej powierzchni głowy osiagnięto wartości HIC od 1300 do 5200 przy wartości przeciętej wynoszącej 2900 HIC. Przy wszystkich wymienionych kryteriach, przede wszystkim z modelami skierowanymi w jedną stronę, przyspieszenie obrotowe pozostaje nieuwzględnione, pomimo przyjęcia założenia, że może ono wywoływać zranienia bez kontaktu z jakąkolwiek powierzchnią. Również zastosowane przyspieszenie liniowe może być zakwestionowane, ponieważ ogranicza się ono do środka masy głowy, natomiast $\mathrm{w}$ rzeczywistości kierunki uderzenia nie są centryczne i wywołują obrót głowy, co jest związane $\mathrm{z}$ występowaniem przyspieszenia obrotowego. Można więc przyjąć założenie, że modele przedstawiają tylko część uwzględnionych mechanizmów powstawania obrażeń [1].

\subsection{Kryteria dotyczące uszkodzeń kości twarzy i szyi pasażera}

Do najważniejszych kości twarzy należą kości policzkowe i szczęki. Kości te mogą być obciążone oddzielnie lub razem. Z przeprowadzonych badań wynika, że szkielet twarzy stawia bardzo duży opór, jeśli uderza on na miękką powierzchnię. Przy prędkościach głowy wynoszących od 14,4 km/h $(4 \mathrm{~m} / \mathrm{s})$ do $64,8 \mathrm{~km} / \mathrm{h}(18$ $\mathrm{m} / \mathrm{s}$ ) nie stwierdzono ani jednego pęknięcia,przy czym wartości przyspieszeń znajdowały się poniżej $60 \mathrm{~g}$ $\left(588.6 \mathrm{~m} / \mathrm{s}^{2}\right)$. W tabeli 4 podano dane dotyczące wytrzymałości kości twarzy pasażera.

\section{Wytrzymałość kości twarzy pasażera ustalona na drodze eksperymentalnej [25]}

Tabela 4

\begin{tabular}{|c|c|c|c|c|c|}
\hline \multirow[t]{2}{*}{ L.p. } & \multirow{2}{*}{$\begin{array}{l}\text { Rodzaj } \\
\text { kości }\end{array}$} & \multirow{2}{*}{$\begin{array}{c}\text { Sposób } \\
\text { uderzenia }\end{array}$} & \multicolumn{2}{|c|}{ Siła uderzenia w [N] } & \multirow{2}{*}{$\begin{array}{c}\text { Wielkość } \\
\text { próby } \\
\text { losowej }\end{array}$} \\
\hline & & & $\begin{array}{l}\text { wartość } \\
\text { średnia }\end{array}$ & zakres siły & \\
\hline 1. & $\begin{array}{l}\text { Kość } \\
\text { policz- } \\
\text { kowa }\end{array}$ & $\mathrm{a}, \mathrm{b}$ & 1717 & $614 \div 3470$ & 19 \\
\hline 2. & $\begin{array}{c}\text { Kość } \\
\text { policz- } \\
\text { kowa }\end{array}$ & $\mathrm{a}, \mathrm{c}$ & 1665 & $925 \div 2850$ & 10 \\
\hline 3. & $\begin{array}{l}\text { Kość } \\
\text { policz- } \\
\text { kowa }\end{array}$ & d & 1259 & $845 \div 1665$ & 5 \\
\hline 4. & $\begin{array}{c}\text { Kość } \\
\text { policz- } \\
\text { kowa }\end{array}$ & e & 2297 & $1600 \div 3360$ & 7 \\
\hline 5. & $\begin{array}{c}\text { Kość } \\
\text { jarzmowa }\end{array}$ & $\mathrm{c}$ & 1535 & $925 \div 2110$ & 17 \\
\hline 6. & $\begin{array}{l}\text { Szczęka } \\
\text { górna }\end{array}$ & $\mathrm{c}$ & 1148 & $623 \div 1980$ & 13 \\
\hline 7. & $\begin{array}{c}\text { Szczęka } \\
\text { dolna }\end{array}$ & $\mathrm{b}$ & $\mathrm{f}$ & $778 \div 934$ & $\mathrm{f}$ \\
\hline 8. & Żuchwa & $\mathrm{b}$ & $\mathrm{f}$ & $1558 \div 1780 \mathrm{~g}$ & $\mathrm{f}$ \\
\hline 9. & Żuchwa & $\mathrm{b}$ & $\mathrm{f}$ & $1290 \div 1445 \mathrm{~g}$ & $\mathrm{f}$ \\
\hline 10. & Żuchwa & $\mathrm{c}$ & 3100 & $890 \div 4110$ & 9 \\
\hline 11. & Żuchwa & $\mathrm{h}$ & 1918 & $818 \div 3405$ & 9 \\
\hline
\end{tabular}

a- uderzenie kości szczękowej z bliskiej odległości

b- sztywne, ptaskie ciało o średnicy Ø $29 \mathrm{~mm} \mathrm{z} \mathrm{wykta-}$ dzina gabkowq o grubości $5 \mathrm{~mm}$

c- jak $w$ b, przy innej wyktadzinie o grubości wynoszacej $5 \mathrm{~mm}$

$d$ - odbojnik o średnicy Ø $29 \mathrm{~mm} z$ warstwa thumiaca e- odbojnik o średnicy Ø $65 \mathrm{~mm} z$ warstwa tlumiaca f-blizej nieopisany

g-dolny zakres sił, przy którym nastapi pęknięcie

h- sztywny, plaski odbojnik o wymiarach $25 \times 100 \mathrm{~mm}$ $z$ wyktadzinq o grubości $5 \mathrm{~mm}$ 
Analizując bezpośrednie uderzenia na szyję pasażera i zakres siły, jaki jest ona w stanie przenieść okazuje się, że przednia część szyi jest tak miękka, iż po przyjęciu uderzenia droga powietrza do płuc może być łatwo zablokowana. W wyniku przeprowadzonych prób doświadczalnych okazało się, że występują sporadyczne zjawiska pęknięć tarczycy przy działaniu sił w przedziale 890 do $1100 \mathrm{~N}$ i krtani 770 do $1000 \mathrm{~N}$ [2]. Przy oddzielnie wykonanych próbach na chrząstkach obydwu organów ustalono średnią siłę powodująca pęknięcia na poziomie $180 \mathrm{~N}$ dla chrząstki tarczycy oraz $250 \mathrm{~N}$ dla krtani. Dla obydwu chrząstek, które przy $50 \%$ zgnieceniu były obciążone za pomoca urządzenia udarowego o średnicy $\varnothing 38 \mathrm{~mm}$ ( pole 11 $\mathrm{cm}^{2}$ ), zarejestrowano siłę wynoszącą $490 \mathrm{~N}$. Wprawdzie ustalona siła nie była daleka od pełnego ściśnięcia krtani, ale otrzymano wyniki, które odbiegały znacznie od wyników innych doświadczeń. Próby przeprowadzone $\mathrm{z}$ urządzeniem udarowym o powierzchni $6,5 \mathrm{~cm}^{2}$ i siłą 400 do $450 \mathrm{~N}$ prowadziły do rzadkich pęknięć ww. części ciała.

\subsection{Kryteria dotyczące klatki piersiowej i brzucha}

Pomiary przeprowadza się, przyjmując jako kryterium wciśnięcie klatki piersiowej wyrażone w mm lub wyrażone $\mathrm{w}$ procentach stłuczenia, biorąc za bazę grubość klatki piersiowej przed przeprowadzeniem badań. Najczęstszym „kryterium Huelkego” przyjmowanym do analiz jest wielkość wciśnięcia wynosząca maksymalnie $44 \mathrm{~mm}$, aby uniknąć złamania żeber. Natomiast przy wciśnięciu wynoszącym 64 do $76 \mathrm{~mm}$ należy liczyć się z poważnymi obrażeniami zakwalifikowanymi jako 3-ciego stopnia w skali AIS [2]. Innym kryterium wystapienia wewnętrznych obrażeń przyjętym przez Verriesta i Chapona jak również Viano i Lau jest stosunek wciśnięcia do początkowej grubości klatki piersiowej wynoszący maksimum 0,4 [3, 11,12,13,14 i 15]. Doświadczenia przeprowadzone z ochotnikami pokazały, że wciśnięcie klatki o $20 \%$ jest niegroźne i jest całkowicie odwracalne, natomiast podczas badań na zwłokach ludzkich przy $40 \%$ wciśnięciu stwierdzono bardzo liczne złamania żeber klatki piersiowej. W następstwie tego zaproponowano górną granicę wciśnięcia klatki piersiowej wynosząca 35\%. (ang. ,maximal chest compression”).

Podczas uderzenia czołowego w klatkę piersiowa, zamiast głębokości wciśnięcia można mierzyć też przyspieszenie $w$ rejonie kręgosłupa. Jako kryterium zaleca się maksymalne przyspieszenie wynoszące $60 \mathrm{~g}$ $\left(588,6 \mathrm{~m} / \mathrm{s}^{2}\right)$ w czasie $3 \mathrm{~ms}$. Powyższe kryterium można skonfrontować z innymi danymi literaturowymi, wg których $\mathrm{w}$ przypadku akrobaty skaczącego $\mathrm{z}$ wysokości $17,4 \mathrm{~m}$ na materac przyspieszenie działające na kręgosłup wynosi $46 \mathrm{~g}\left(451 \mathrm{~m} / \mathrm{s}^{2}\right)$, natomiast kiedy upada on na brzuch, zmierzono na mostku przyspieszenie wynoszące $380 \mathrm{~g}\left(3727 \mathrm{~m} / \mathrm{s}^{2}\right)$ i na kręgosłupie $68 \mathrm{~g}\left(667 \mathrm{~m} / \mathrm{s}^{2}\right)$. Przy badaniu serii uderzeń na klatkę piersiową wykryto, że maksymalne przyspieszenie kręgosłupa na wysokości klatki piersiowej jest gorszym kryterium rozstrzygającym o ewentualnym występowaniu obrażeń i powinno ono być zastąpione przez maksymalne wciśnięcie klatki piersiowej.

\subsection{Ocena kryteriów biomechanicznych}

Kryteria biomechaniczne dla klatki piersiowej sprowadzają się do:

$>$ kryterium VC ( ang. „Viscous Criterion”) opracowane na bazie energii pochłoniętej przez klatkę piersiowa, uwzględnia prędkość jej deformacji; wychodzi się tutaj z założenia, że przy prędkości odkształcenia mniejszej niż $3 \mathrm{~m} / \mathrm{s}(10,8 \mathrm{~km} / \mathrm{h})$ można zastosować kryterium maksymalnego wciśnięcia. Ze względu na wiskotyczność klatki piersiowej prędkość odkształcenia ma duży wpływ na zakres wciśnięcia i tym samym na niebezpieczeństwo zranienia miękkich tkanek ciała.

Kryterium VC można wyrazić za pomoca wzoru:

$$
V C=\dot{y} \cdot \frac{y}{D}
$$

gdzie:

$$
V=\dot{y} \quad \text { i } \quad C=\frac{y}{D}
$$

oraz:

D-grubość klatki piersiowej przed zderzeniem y- chwilowe odkształcenie (wciśnięcie) klatki piersiowej

$\dot{y}$-chwilowa prędkość deformacji klatki piersiowej.

$>$ kryterium TTI ( ang. „Thoraric Trauma Index") opracowane na statystycznych badaniach 49 wypadków śmiertelnych; definiuje się je za pomocą wzoru:

$$
\quad T T I=1,4 A_{e}+\frac{0,5 \cdot\left(R_{e}+S_{e}\right)}{75} \cdot M_{e}
$$

$\mathrm{A}_{\mathrm{e}}$-wiek (rocznik) pasażera

e- wskaźnik równoważny dla ofiar śmiertelnych i manekinów

$\mathrm{M}_{\mathrm{e}}$-masa pasażera [kg]

$\mathrm{R}_{\mathrm{e}}-$ maksymalne efektywne przyspieszenie żebra [g]

$\mathrm{S}_{\mathrm{e}}$ - maksymalne boczne przyspieszenie kręgosłupa [g].

Kryterium VC jest przeznaczone głównie do analizy wystąpienia ewentualnych obrażeń, wynikających z czołowego uderzenia $\mathrm{w}$ klatkę piersiową pasażera. Obydwa kryteria VC i TTI są stosowane do analiz skutków wypadków wynikających z bocznych uderzeń. 
Kryteria biomechaniczne można stosować tylko do określonego zakresu ludzkiego ciała i w ogólnym przypadku tylko dla określonego rodzaju obrażeń. Ofiara wypadku cierpi jednak zwykle z powodu zróżnicowanych obrażeń doznanych podczas wypadku, które działając jednocześnie mogą się jeszcze bardziej pogłębiać. Nie można stosować tylko jednego kryterium dla jednej części ciała. $\mathrm{O}$ wiele bardziej należy się troszczyć o całkowitą ochronę pasażera. Na przykładzie transportu samochodowego okazuje się, że wartości wskaźnika HIC można zmniejszyć, jeśli przyjmie się, że pasażer posiada zapięty pas $\mathrm{w}$ rejonie podbrzusza. W tym przypadku jednak bardziej obciążone są kości uda. W przypadku komunikacji kolejowej należy uwzględnić inne rozwiązania niż w komunikacji samochodowej, ponieważ pasażerowie nie posiadają pasów bezpieczeństwa. W tym przypadku nie trzeba uwzględniać sił wywieranych na podbrzusze ani też obciążeń na nogi. W rzeczywistości kinematyka podróżnych pociagu zmusza do tego, aby uwzględniać ochronę tych części ciała, które nie są obciążone w komunikacji samochodowej.

Dla celów informacyjnych kryteria biomechaniczne obowiązujące $\mathrm{w}$ transporcie samochodowym przedstawiono w tabeli 5 [25].

Zestawienie kryteriów biomechanicznych dla poszczególnych części ciała pasażera w komunikacji samochodowej

Tabela 5

\begin{tabular}{|c|c|c|c|}
\hline L.p. & Część ciała & $\begin{array}{c}\text { Kryterium bezpieczeń- } \\
\text { stwa }\end{array}$ & Wartość \\
\hline 1. & Głowa & $\begin{array}{c}\text { Wartość wskaźnika } \\
\text { GAMBIT }\end{array}$ & 1,0 \\
\hline 2. & Szyja & Moment zginający & $\begin{array}{c}370,0 \\
\mathrm{Nm}\end{array}$ \\
\hline 3. & $\begin{array}{c}\text { Klatka pier- } \\
\text { siowa }\end{array}$ & $\begin{array}{c}\text { Nacisk wywołujący wci- } \\
\text { śnięcie }\end{array}$ & $40 \mathrm{~mm}$ \\
\hline 4. & Ramiona & Siła kontaktu na rękach & $3,8 \mathrm{kN}$ \\
\hline 5. & $\begin{array}{c}\text { Podbrzusze } \\
\left(\alpha>20^{\circ}\right)\end{array}$ & $\begin{array}{r}\text { Przyspieszenie miednicy } \\
13,0 \mathrm{~g}\end{array}$ \\
\hline 6. & Podbrzusze & $\begin{array}{c}\text { Przyspieszenie miednicy } \\
\left(\alpha \leq 20^{\circ}\right)\end{array}$ & $80,0 \mathrm{~g}$ \\
\hline 7. & Nogi & $\begin{array}{r}\text { Siła kontaktu działająca } \\
\text { na nogi }\end{array}$ & $10,0 \mathrm{kN}$ \\
\hline
\end{tabular}

\section{Wytyczne do konstruowania pojazdów szy- nowych w komunikacji osobowej, zabezpie- czające pasażera przed obrażeniami w przypadku zderzeń}

W celu sformułowania wytycznych do konstruowania pojazdów szynowych w komunikacji osobowej, które mają zagwarantować bezpieczeństwo pasażera podczas zderzeń, przeprowadzono obliczenia symulacyjne dla 24 przypadków różnych konfiguracji zderzeń [25]. W oparciu o wyniki obliczeń sformułowano następujące wymagania wytrzymałościowe dla prędkości zderzenia $54 \mathrm{~km} / \mathrm{h}(15 \mathrm{~m} / \mathrm{s})$ :

- zderzaki powinny być przystosowane do przeniesienia siły wynoszącej $1500 \mathrm{kN}$, co odpowiada obecnym wymaganiom technicznym, stawianym pojazdom i zarazem umożliwia maksymalne zastosowanie zróżnicowania sztywności poszczególnych elementów pociagu; powyżej siły $1500 \mathrm{kN}$ mogą wystąpić pęknięcia elementów mocowania zderzaków, jednakże bez wystapienia uszkodzeń końców pudła pojazdu

- należy zastosować wymienialne elementy pochłaniające energię $\mathrm{z}$ odpowiednią długością deformacji, zainstalowane za zderzakami, do przeniesienia siły do $1750 \mathrm{kN}$ tak, aby umożliwić zadziałanie urządzeń zapobiegających uniesieniu się pojazdu; powyżej 1750 $\mathrm{kN}$ następuje zgniot elementów pochłaniających (ang. ,crashelemente”)

- strefy pojazdu, w których są dopuszczalne pęknięcia ( niem. „Sollbruchbereiche”) powinny być zaprojektowane na bezpieczne przeniesienie siły wynoszącej $2000 \mathrm{kN}$; powyżej tej siły następuje zgniot elementów poprzez plastyczne odkształcenie końców pudła wagonu

- strefy przedziałów dla podróżnych należy projektować tak, aby mogły przenieść siłę $4000 \mathrm{kN}$.

Ww. wymagania nie powinny powodować rozwoju pojazdów o dużej masie własnej. Ponadto stwierdzono, że jeśli prędkość zderzenia przekracza $30 \mathrm{~km} / \mathrm{h}$ $\left(8.33 \mathrm{~m} / \mathrm{s}^{2}\right)$, wówczas wzrasta niebezpieczeństwo utraty zdrowia i życia przez pasażerów co najmniej o $50 \%$ (przy stopniu AIS $>3$ ). Przy projektowaniu pudeł wagonów osobowych zaleca się, aby podczas zderzenia został zrealizowany „, ich stopniowy zgniot”, co można uzyskać przez przejście z jednej strefy do drugiej przy zastosowaniu współczynnika bezpieczeństwa wynoszącego 1,5 do 2 . Jeśli przyjmie się, że wytrzymałość czołownicy ostoi wagonu jest ograniczona do $2000 \mathrm{kN}$, to wówczas strefa dopuszczalnych pęknięć występuje w zakresie 3000 do 4000 kN, a następne przedziały dla podróżnych podlegają trwałym deformacjom przy działaniu sił 4500 do 6000 $\mathrm{kN}$.

W przypadku zderzenia pojazdów o podobnej konstrukcji na prostym odcinku toru kolejowego:

przy prędkościach nabiegania poniżej $14,4 \mathrm{~km} / \mathrm{h}(4,0 \mathrm{~m} / \mathrm{s})$ :

- przy prędkości mniejszej niż $14,4 \mathrm{~km} / \mathrm{h}$ energia zderzenia musi być pochłonięta $\mathrm{w}$ ramach przewidzianego skoku zderzaków lub sprzęgu samoczynnego 
- przy prędkości mniejszej niż 7,2 km/h $(2,0 \mathrm{~m} / \mathrm{s})$ maksymalne przyspieszenie wzdłużne w pudle wagonu pojazdu nie może przekroczyć $2 \mathrm{~g}\left(19,62 \mathrm{~m} / \mathrm{s}^{2}\right)$

- przy prędkości zawierającej się w przedziale 7,2 do $14,4 \mathrm{~km} / \mathrm{h}$ maksymalne przyspieszenie wzdłużne $\mathrm{w}$ pudle wagonu pojazdu nie może przekroczyć $3 \mathrm{~g}$ $\left(29,43 \mathrm{~m} / \mathrm{s}^{2}\right)$

- poniżej prędkości $14,4 \mathrm{~km} / \mathrm{h}$ żaden $\mathrm{z}$ pasażerów nie może doznać jakichkolwiek obrażeń.

- przy prędkościach nabiegania większych od $14,4 \mathrm{~km} / \mathrm{h}(4.0 \mathrm{~m} / \mathrm{s})$ i mniejszych od $28,8 \mathrm{~km} / \mathrm{h}(8 \mathrm{~m} / \mathrm{s})$ :

- przy prędkości większej niż $14,4 \mathrm{~km} / \mathrm{h}$ energia zderzenia nie jest już pochłaniana przez sprzęg

- przy prędkościach większych niż 14,4 $\mathrm{km} / \mathrm{h}$ i mniejszych niż $28,8 \mathrm{~km} / \mathrm{h}$ musi być uniemożliwione podnoszenie się pojazdu przez zastosowanie odpowiednich urządzeń zabezpieczających pojazd przed „unoszeniem się”; funkcja oraz wydajność tych urządzeń musi być zachowana przez cały czas zmiany wysokości pojazdu szynowego podczas eksploatacji, spowodowanej między innymi przemieszczeniami dynamicznymi

- przy prędkościach, które nie przekraczają $28,8 \mathrm{~km} / \mathrm{h}$ energia zderzenia musi być pochłonięta przez urządzenie pochłaniąjąco-zderzne, które można łatwo wymienić; maksymalne przyspieszenie wzdłużne nie może przekroczyć $5 \mathrm{~g}$ $\left(49,05 \mathrm{~m} / \mathrm{s}^{2}\right)$

- przy prędkościach nabiegania większych od $28,8 \mathrm{~km} / \mathrm{h}(8 \mathrm{~m} / \mathrm{s})$ i mniejszych od 65 $\mathrm{km} / \mathrm{h}(18 \mathrm{~m} / \mathrm{s})$ :

- przy prędkości mniejszej niż $65 \mathrm{~km} / \mathrm{h}$ energia zderzenia musi być przejęta łącznie przez zderzaki, elementy zderzno-pochłaniające jak również stopniowe odkształcenie pudła wagonu; odkształcenie pudła wagonu nie może przekroczyć $1000 \mathrm{~mm}$
- dla maszynisty musi być przewidziana bezpieczna przestrzeń, gwarantująca przeżycie.

Przy prędkości większej od $65 \mathrm{~km} / \mathrm{h}(18 \mathrm{~m} / \mathrm{s})$ występuje katastrofa kolejowa i nie podaje się wytycznych. Podczas konstrukcji wewnętrznego wyposażenia pojazdu należy przestrzegać następujących zasad:

- pokrycie wszystkich metalowych powierzchni za pomocą elastycznej wykładziny

- bardzo często stosowane ściany szklane muszą być poddane kontrolnym testom z uwagi na bezpieczeństwo dla pasażerów podczas zderzeń

- nie należy stosować przedmiotów o ostrych krawędziach

- w przypadku przedziałów bagażowych należy stosować ścianki działowe, aby uniemożliwić upadek bagażu na pasażera

- wykonać szczególną kontrolę pod kątem sprawdzenia, czy składane stoliki stwarzają niebezpieczeństwo dla podbrzusza pasażera.

Ważnym elementem wyposażenia wewnętrznego jest siedzenie pasażera, które zgodnie z kartą UIC 567 [18] musi wytrzymać siłę wzdłużną wynoszącą 1500 $\mathrm{N}$ lub przyspieszenie $2 \mathrm{~g}\left(19,62 \mathrm{~m} / \mathrm{s}^{2}\right)$ przy masie pasażera $75 \mathrm{~kg}$. W tym przypadku wychodzi się z założenia, że całą masę podróżnego przenosi oparcie siedzenia, co nie ma całkowitego potwierdzenia w rzeczywistości. Jak wynika z analiz doświadczalnych, na pasażera może działać składowa siła bezwładności na wysokości 2/3 oparcia, w kierunku wzdłużnym i osiągająca maksymalną wartość $2250 \mathrm{~N}$, co odpowiada maksymalnemu opóźnieniu wynoszącemu 3g (29,43 $\mathrm{m} / \mathrm{s}^{2}$ ). Ww. wartość siły wynika $\mathrm{z}$ równania równowagi momentów sił względem dolnej krawędzi oparcia siedzenia. Ten przypadek występuje wtedy, gdy miejsce siedzące jest obrócone w kierunku przeciwnym do kierunku jazdy. Jak wynika z obecnego stanu obowiązujących dokumentów, przypadek ten nie został uwzględniony w przepisach jako obligatoryjny. Przykłady nowoczesnych konstrukcji tramwajowych wyposażonych $\mathrm{w}$ elementy pochłaniająco-zderzne oraz $\mathrm{w}$ urządzenia zabezpieczające pojazd przed „wspinaniem się" są przedstawione na rys. 4 i 5 [16]. 


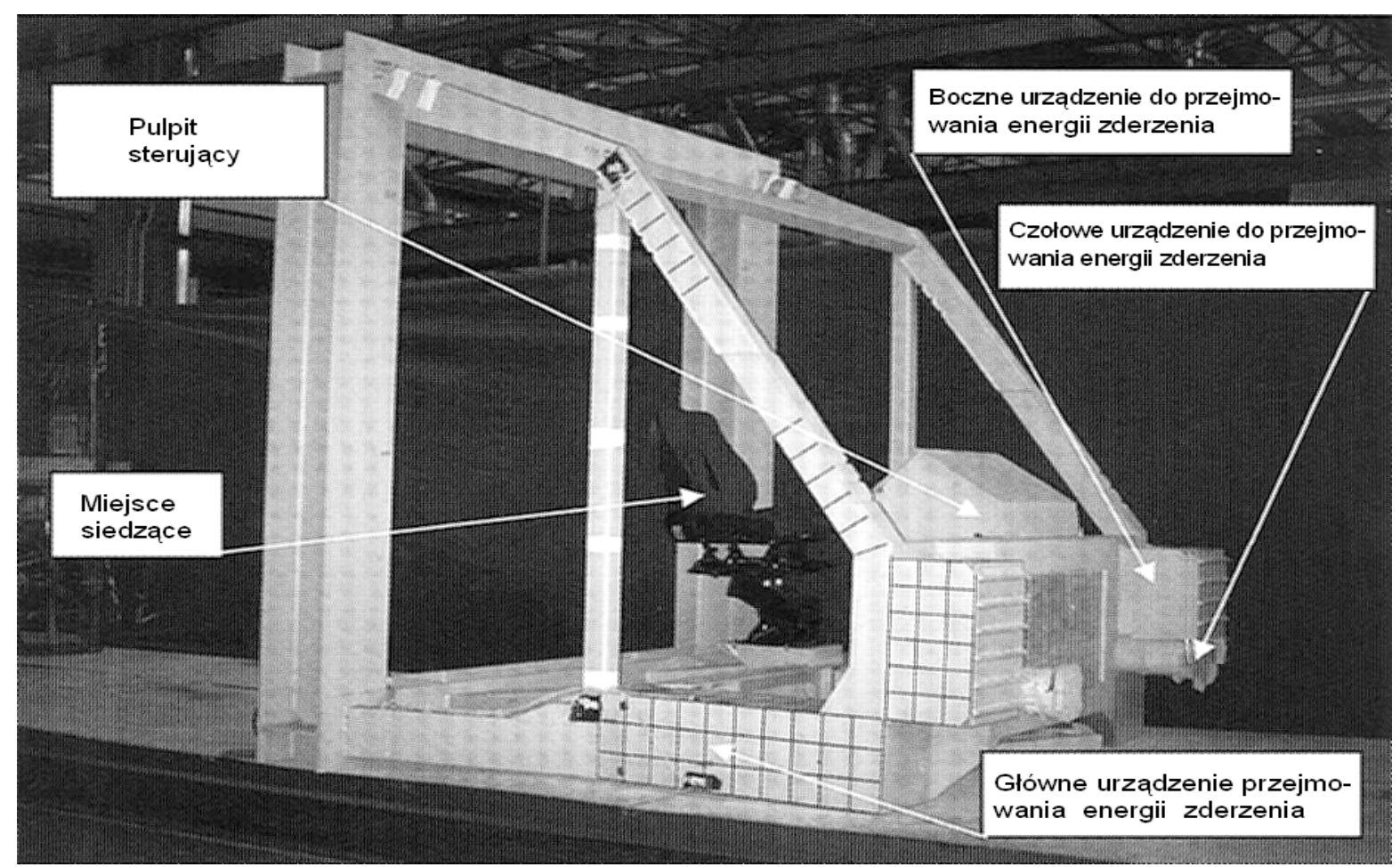

Rys.4. Nowoczesne rozwiązanie konstrukcji kabiny tramwajowej z wewnętrznymi oraz zewnętrznymi ,strefami deformacji” w przypadku zderzeń (zaprojektowanej przez Bombardier Transportation Portugal, producent: Ansoldo Breda Pistola)

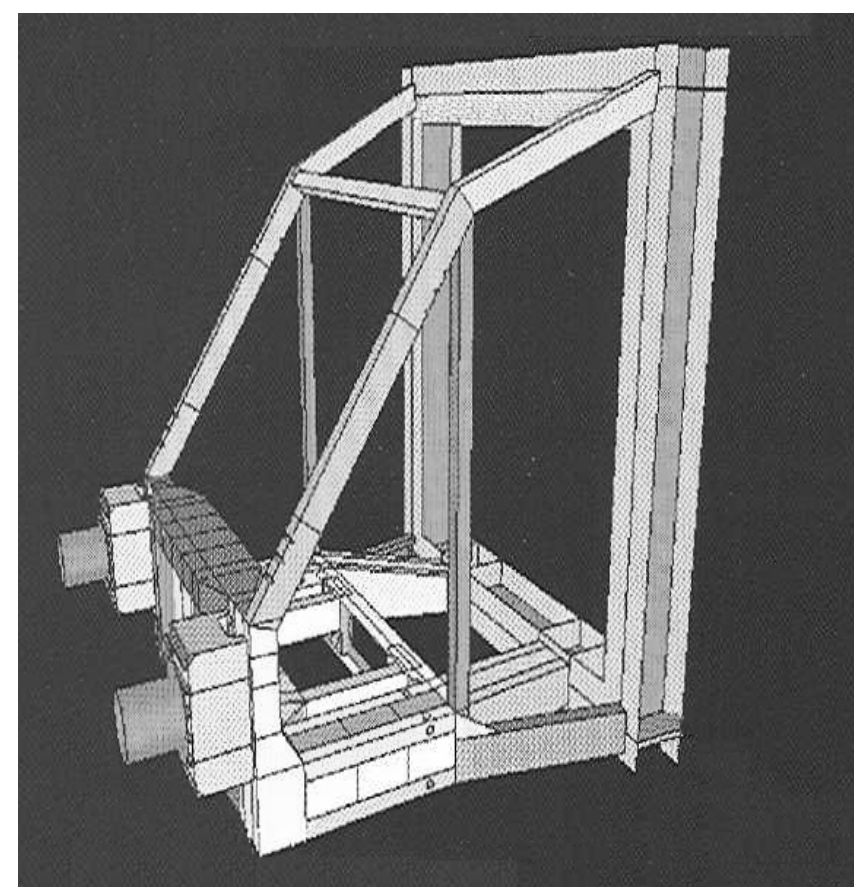

$\mathbf{a}$

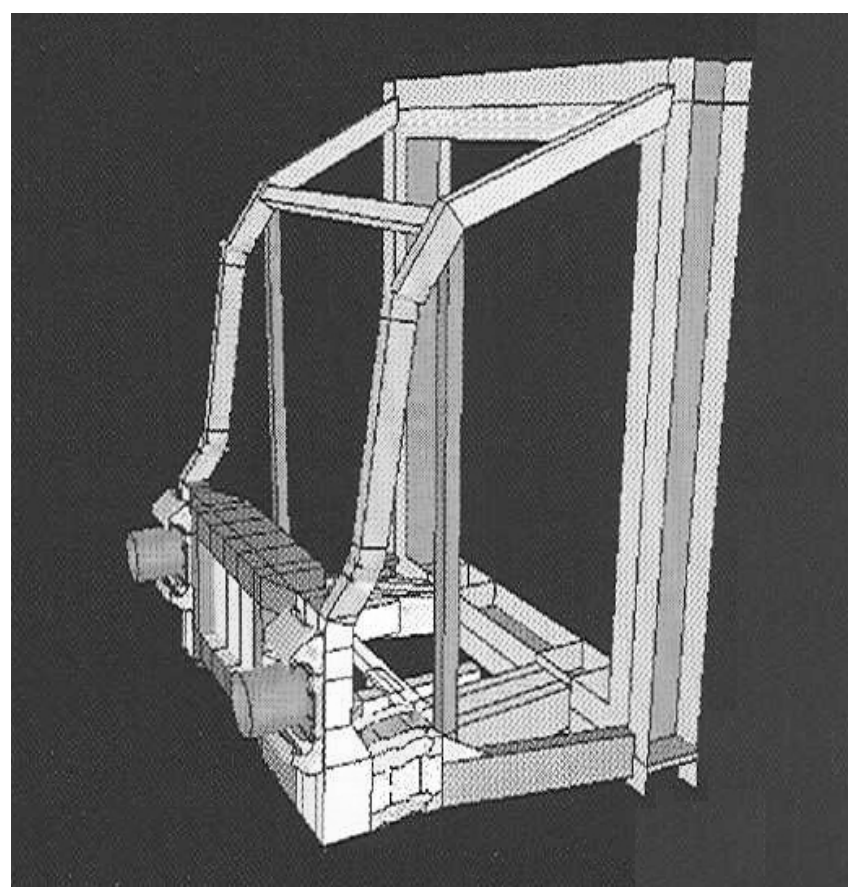

b

Rys.5. Konstrukcja kabiny tramwajowej firmy Alstom ( La Rochelle)

a) widok konstrukcji przed zderzeniem

b) widok konstrukcji po zderzeniu ( kabina częściowo odkształcona, strefa drzwi niezdeformowana) 


\section{Zakończenie}

Kryteria oceny przy zderzeniach dla pojazdów szynowych komunikacji osobowej mają odmienny charakter niż dla wagonów towarowych $[4,5$ i 6$]$ i wynikają ze specyfiki, związanej z zapewnieniem bezpieczeństwa dla pasażerów i personelu obsługującego przed obrażeniami w trakcie zderzeń. Ważną rolę pełnią tutaj kryteria biomechaniczne, za pomocą których można dokonać kwalifikacji urządzeń wewnętrznych, przy uwzględnieniu bezpieczeństwa podróżnych. Przyjmuje się założenie, że teoretycznie da się oszacować, jak ciężkie w skutkach jest zderzenie i jak działa na ciało ludzkie. Rozpatrując problematykę zderzeń pojazdów szynowych bezspornym jest fakt, że najcięższym zderzeniem jest zderzenie czołowe, które można podzielić na trzy kategorie:

- czyste zderzenie czołowe

- czołowe zderzenie z ,unoszeniem się" pojazdu

- czołowe zderzenie połączone z niestabilnościa pociagu i wykolejeniem.

Pierwsza kategoria zderzeń należy do tych, które konstruktor może najlepiej opanować. W tym przypadku chodzi o to, aby wykorzystać wszystkie możliwe strefy „odkształcalne” pojazdu, w celu pochłonięcia energii zderzenia bez występowania odkształceń przedziałów dla podróżnych. Koncepcja stref pojazdu przeznaczonych do zniszczenia umożliwia lepsze zabezpieczenie wagonu przed skutkami zderzeń.

Drugą kategorię zderzeń określa się mianem katastrofy kolejowej i należy na ścianach czołowych pojazdu przewidzieć zabudowę urządzeń zapobiegających „unoszeniu się” wagonu.

Trzecia kategoria zderzeń występuje przy wysokich prędkościach i stanowi poważną katastrofę kolejową. Jeśli pojazd ulega wykolejeniu w wyniku zderzenia, to istnieje bardzo duże prawdopodobieństwo ponownego zderzenia $\mathrm{z}$ elementem budowli stałej infrastruktury kolejowej np. słupem trakcyjnym ( boczne zderzenie pojazdu szynowego).

Istotna zaletą pojazdu szynowego $\mathrm{w}$ stosunku do samochodu jest to, że pojazd szynowy może przejąć znacznie większą energię zderzenia, wykazując odkształcenia trwałe. $Z$ tego powodu podróżni w samochodzie są zobowiązani do korzystania z pasów bezpieczeństwa, aby zwiększyć szanse przeżycia w wyniku zderzenia. Podróżni w pojazdach szynowych są narażeni na umiarkowane przyspieszenia, które nie powodują konieczności stosowania pasów bezpieczeństwa.

\section{Literatura}

[1] Balas M., Ramet M.: Les mécanismes des liaisons cérébrales par choc et les problèmes de leur évaluation. Rapport INRETS No 791988.

[2] Huelke D.F., Melvin J.W.: Anatomy injury frequency, biomechanics and human tolerance. SAE paper $n r$ 800098, 1980.

[3] Lau I.V., Viano I.V.: The viscous criterion. Bases and applications of an injury severity index for soft tissues. SAE Paper. Proceedings of the 30 th Stapp Car Crash Conference. San Diego, 1986.

[4] Nowicki J., Sobaś M.: Kryteria oceny zabezpieczenia pojazdów szynowych przed skutkami zderzeń. Pojazdy Szynowe nr 3/2006.

[5] Nowicki J., Sobaś M.: Wymagania stawiane elementom pochtaniajacym energię zderzenia $w$ wagonach-cysternach. Pojazdy Szynowe $n r$ 4/2006.

[6] Nowicki J., Sobaś M.: Przedsięwzięcia materiatowe i konstrukcyjne zwiększajace bezpieczeństwo pojazdów szynowych przed skutkami zderzeń. Pojazdy Szynowe nr 1/2007.

[7] Scholes A.: Railway passenger vehicle design loads and structural crashworthiness. Proc. Instn. Mech. Engrs., 1987.

[8] Soltis S.J., Olcott J.W.: The development of dynamic performance standards for general aviation aircraft seats. SAE Paper.Crash $d y$ namics of general aviation aircraft. 1985.

[9] Stalnaker R.L., Lin A.C., Guenther D.A.: The Application of the New Mean Strain Criterion. IRCOBI /AAAM Conf. on the Biomechanics of Impacts. Göteborg, Sweden 1985.

[10] Stalnaker R.L. Low T.C., Lin A.C.: Translation energy criteria and its correlation with head injury in the sub-human primate. IRCOBI Conf. on the Biomechanics of Impacts. Birmingham, United Kingdom, 1987.

[11] Verriest J., Chapon A.: Validity of thoracic injury criteria based on the number of rib factures. 10 th Experimental Safety Vehicle Conf. Oxford-England 1985.

[12] Viano D.C., Lau I.V.: Role of impact velocity and chest compression in thoracic injury. Aviat. Space Enviro. Med. nr 54, 1985.

[13] Viano D.C., Lau I.V.: Thoraric impact: a viscous tolerance criterion. 10 th Experimental Safety Vehicle Conf. Oxford-England 1985.

[14] Viano D.C.: Limits and challenges of crash protection. Accident Anal. 1988.

[15] Wang J.T.: Analytical studies of injury criteria for the thorax. Journal of Biomechanical Engineering $\mathrm{Nr}$ 111, 1985. 
[16] Wolter W.: Kollisionssichere Schienenfahrzeuge -Empfehlungen für Hersteller und Betreiber. ZEV Rail. Glasers Annalen $\mathrm{Nr}$. 128. Tagungsband Graz 2004.

[17] Karta UIC 566: Obciażenia pudet wagonów pasażerskich i ich części dobudowanych.3-cie wydanie $z 1.01 .1990 \quad z$ uzupetnieniem $z$ 1.07.1994

[18] Karta UIC 567: Postanowienia ogólne dla wagonów osobowych. 2-gie wydanie $z$ 11.2004.

[19] Norma SAE J374: Passenger car roof crush test procedure. Styczeń 1980.

[20] Norma SAE J885: Human tolerance to impact conditions as related to motor vehicle design. Lipiec 1986.

[21] Norma SAE J 996: Inverted vehicle drop test procedure. Styczeń 1980.

[22] pr EN 15 227: Kolejnictwo. Wymagania odpornościowe na zderzenia nadwozi pojazdów szynowych. (Railway applications. Crashworthiness requirements for railway vehicle bodies). Kwiecień 2005.
[23] Raport ERRI B205/Rp.1 Podstawowe zasady bezpieczeństwa przed skutkami zderzeń pojazdów szynowych. Załacznik 1 do pisma $B$ 205.97 z 5.12.1994. ( Leitende Grundsätze der Aufprallsicherheit von Eisenbahnfahrzeugen). Utrecht, listopad 1994.

[24] Raport ERRI B205/Rp.1 Podstawowe zasady bezpieczeństwa przed skutkami zderzeń pojazdów szynowych.(Leitende Grundsätze der Aufprallsicherheit von Eisenbahnfahrzeugen). Utrecht, luty 1995.

[25] Raport ERRI B 106/Rp.20: Wytrzymałość na zderzenia pudta wagonu osobowego. Oddziatywania zderzeń zdeterminowanych wypadkiem na wagony osobowe. Zalecenia warunków technicznych dostawy. ( Stossfestigkeit des Wagenkastens von Reisezugwagen. Auswirkungen unfallbedingter Stösse auf Untersuchung. Vorschläge für technische Lieferbedingungen ). Utrecht 12/1993 